\title{
Review of varicella-zoster virus infections in pregnant women and neonates
}

\author{
A. Sauerbrei \\ Institute of Virology and Antiviral Therapy, Friedrich-Schiller University of Jena, Jena, Germany;Adreas.Sauerbrei@med.uni-jena.de
}

Received 29 October 2009; revised 7 December 2009; accepted 9 December 2009.

\begin{abstract}
Even though varicella is rare in pregnancy, the disease can lead occasionally to disastrous illnesses for both the mother and her neonate. By contrast, normal zoster is not associated with special problems during pregnancy and perinatal period. Pregnant women, who contract varicella, are at risk of varicella pneumonia which must be regarded as medical emergency. At any stage during pregnancy, chickenpox may cause intrauterine infection. The consequences for the fetus depend on the time of maternal disease. During the first two trimesters, maternal varicella may result in congenital varicella syndrome which may occur in nearly $2 \%$. Typical symptoms are skin lesions in dermatomal distribution, neurological defects, eye diseases, and skeletal anomalies. Maternal infection near term is associated with a substantial risk of intrauterine acquired neonatal chickenpox in the neonate. If the mother develops varicella rash between day 4 (5) ante partum and day 2 post partum, generalized neonatal varicella leading to death in about $20 \%$ of the cases has to be expected. The present paper reviews the clinical consequences and the currently available concepts of prevention, diagnosis, and therapy of varicella-zoster virus infections during pregnancy.
\end{abstract}

Keywords: Varicella-Zoster Virus Infection; Pregnancy; Neonate; Prevention; Diagnosis; Therapy

\section{MATERNAL VARICELLA-ZOSTER VIRUS INFECTIONS AND THEIR CONSEQUENCES}

In most industrial countries, chickenpox is a rare disease during pregnancy, as more than $90 \%$ of women of childbearing age have virus-specific immunoglobulin (Ig) $\mathrm{G}$ class antibodies. The etiological agent, the varicellazoster virus (VZV), is spread by respiratory transmission or direct contact with infectious lesions. Seronegative persons are at high risk of primary infection manifest as varicella. According to a seroepidemiological study in Germany, the prevalence of VZV-specific IgG class antibodies in women of reproductive age is $96-97 \%$ and only $3-4 \%$ of women were found to be susceptible to varicella [1]. The average incidence of varicella in pregnant women has been calculated as $0.7-3$ per 1,000 pregnancies [2-4]. Information on a positive history of varicella correlates well with serological findings. However, VZV IgG can be detected in $85 \%$ of persons with negative history of varicella [5]. Although the clinical course of chickenpox is usually mild, varicella in pregnant women may occasionally lead to serious maternal and fetal diseases (Table 1).

Pregnant women who contract varicella are at risk of severe pneumonia associated with life-threatening ventilatory compromise and death. The disease seems to occur more often in the third trimester [6]. At any stage during pregnancy, chickenpox may cause intrauterine infection. Maternal varicella leading to viremia may transmit the virus to the fetus by either transplacental spread or by ascending infection from lesions in the birth canal. The fetal consequences depend on the time of maternal disease. They range from asymptomatic infection to fetal loss especially in case of severe maternal disease. Neonatal varicella can be expected if a mother contracts chickenpox during the last 3 weeks of pregnancy. After maternal varicella between 4-5 days before and 2 days after delivery, generalized neonatal varicella, leading to death in up to $20 \%$ of the cases, may occur since these neonates have not acquired protecting antibodies [7].

\subsection{Varicella Pneumonia}

Although chickenpox is much less common in adults than in children, the infection is associated with greater morbidity, namely pneumonia, hepatitis and encephalitis. Varicella pneumonia during pregnancy must be regarded as a medical emergency. On the basis of retrospective 
Table 1. Varicella-zoster virus infections and their potential consequences during pregnancy.

\begin{tabular}{|c|c|c|}
\hline Maternal disease & Timing during pregnancy & Consequences for mother, fetus, term neonate \\
\hline \multirow{5}{*}{ Varicella } & At any stage & Intrauterine death, neonatal or infantile zoster \\
\hline & $5-24$ th weeks & Congenital varicella syndrome (risk: $2 \%$, mortality: $30 \%$ ) \\
\hline & At any stage, especially in the third trimester & Maternal pneumonia (risk: $10-20 \%$, mortality: $10-45 \%$ ) \\
\hline & Near term: $\geq 5$ days before delivery & $\begin{array}{l}\text { Neonatal varicella at ages } 10(-12) \text { days (risk: } 20-50 \% \text {, mor- } \\
\text { tality: } 0 \% \text { ) }\end{array}$ \\
\hline & Near term: $\leq 4-5$ days before to 2 days after delivery & $\begin{array}{l}\text { Neonatal varicella } 0-4 \text { days after birth (risk: } 20-50 \% \text {; mor- } \\
\text { tality: } 0-3 \% \text { ); neonatal varicella } 5-10(-12) \text { days after birth } \\
\text { (risk: } 20-50 \% \text {; mortality: } 20-25 \% \text { ) }\end{array}$ \\
\hline Normal zoster & At any stage & No risk for severe maternal, fetal or neonatal infections \\
\hline
\end{tabular}

hospital-based studies, an incidence of $10-20 \%$ among adults with chickenpox has been reported [6,8]. The clinical course is unpredictable and may rapidly progress to hypoxia and life-threatening respiratory failure. Retrospective studies suggest that varicella pneumonia may be more severe, although not more frequent, in pregnant compared to non-pregnant women [9]. Risk factors for the development of pneumonia are smoking and the occurrence of at least 100 skin lesions [10]. The disease usually develops within 3-5 days of the rash and is associated with cough, dyspnea, fever, and tachypnea. Additionally, cyanosis, pleuritic pain in the chest and hemoptysis can occur and secondary bacterial infections are frequent. The chest x-ray findings include a diffuse or miliary/nodular infiltrative pattern often in the peribronchial distribution involving both lungs [11]. Without antiviral treatment, the mortality of the disease may be as high as $45 \%$. However, more recent studies suggest that the mortality has decreased to $10-11 \%$ for both non-pregnant and pregnant patients most likely due to the effects of antiviral therapy and better respiratory management [12]. Nevertheless, the risk of fatal course appears to be considerably higher in pregnant than in non-pregnant immunocompetent adults.

\subsection{Congenital Varicella Syndrome}

Primary VZV infection during first two trimesters of pregnancy may result in intrauterine infection in up to a quarter of the cases [13]. However, the reported rate of spontaneous abortion following acute varicella did not exceed the rate of abortion in pregnant women without chickenpox. Congenital anomalies described as congenital varicella syndrome (CVS) can be expected in about $12 \%$ of infected fetuses [14]. Prospective studies in Europe and North America revealed that the incidence of congenital anomalies after maternal varicella infection in the first 20 weeks of pregnancy is about $1-2 \%[15,16]$. The first case of CVS was reported by Laforet and Lynch in 1947 [17]. Since then, more than 130 neonates born with signs of CVS have been described in the English and German literature [13]. Since most of them have been reported during the last 15-20 years, it can be concluded that many cases of this syndrome were formerly not seen in connection with chickenpox during pregnancy. CVS has generally to be expected after maternal chickenpox between the $5^{\text {th }}$ and $24^{\text {th }}$ gestational weeks. Nearly $80 \%$ of all cases have been observed between the $9^{\text {th }}$ and $20^{\text {th }}$ weeks of gestation. Before the $5^{\text {th }}$ and after the $24^{\text {th }}$ gestational weeks, the probability of CVS is extremely low. The characteristic clinical symptoms consist of skin lesions in dermatomal distribution, neurological defects, eye diseases, and limb hypoplasia (Table 2). Less frequent abnormalities include muscle hypoplasia, affections of the internal organs as well as gastrointestinal, genitourinary, and cardiovascular manifestations [18]. Nearly $30 \%$ of neonates born with signs of CVS died during the first months of life. A follow-up report in the literature demonstrated that in spite of initially poor prognosis a good long-term outcome can occur in patients with CVS [19]. On the basis of the segmental distribution of some of the signs, there was postulated that the CVS is not the immediate consequence of intrauterine varicella, but caused by intrauterine zoster-like VZV reactivations with accompanying encephalitis [20]. Immunologic studies suggest that the fetus is not able to mount a VZV-specific cell-mediated immune response [21].

Case report [22]: After a mother had chickenpox with characteristic skin rash between the $13^{\text {th }}$ and $15^{\text {th }}$ gestational weeks, a stillborn girl with typical clinical signs of CVS was delivered by caesarean section at the $34^{\text {th }}$ week of gestation. Postmortal findings included hypoplasia of the left upper and the right lower limb, dermatomally distributed skin lesions in the region of the left anterior thorax, axilla and shoulder as well as on the right lower extremity (Figure 1). The autopsy and histological investigations revealed microphthalmia of the left eye associated with opticus atrophia and chorioretinitis pigmentosa. Additional findings were coarcatio aortae of preductal type, Meckel's diverticulum, miliary calcified necroses in the lungs, liver and adrenal glands as well as one-sided cell reduction of the motor anterior column of the cervical and lumbar spinal cord. The eumature placenta showed a focal villous fibrosis, 
Table 2. Main symptoms of neonates with congenital varicella syndrome cited in the literature.

\begin{tabular}{|c|c|c|}
\hline \multirow{2}{*}{ Symptoms } & \multicolumn{2}{|c|}{ Neonates $(n=125)$} \\
\hline & n & $\%$ \\
\hline Skin lesions (cicatrical scars, skin loss) & 90 & 72 \\
\hline $\begin{array}{l}\text { Neurological defects or diseases (cortical atrophy, spinal cord atrophy, limb paresis, seizures, microcephaly, } \\
\text { Horner's syndrome, encephalitis, dysphagia) }\end{array}$ & 78 & 62 \\
\hline Eye diseases (microphthalmia, enophthalmia, chorioretinitis, cataract, nystagmus, anisocoria, optic atrophy) & 66 & 53 \\
\hline Limb hypoplasia and other skeletal anomalies & 55 & 44 \\
\hline Intrauterine retardation & 28 & 22 \\
\hline Gastrointestinal abnormalities & 25 & 20 \\
\hline Muscle hypoplasia & 24 & 19 \\
\hline Genitourinary abnormalities & 15 & 12 \\
\hline Affections of internal organs & 15 & 12 \\
\hline Developmental delay & 14 & 11 \\
\hline Defects of the cardiovascular system & 9 & 7 \\
\hline Defects of other organs & 9 & 7 \\
\hline
\end{tabular}

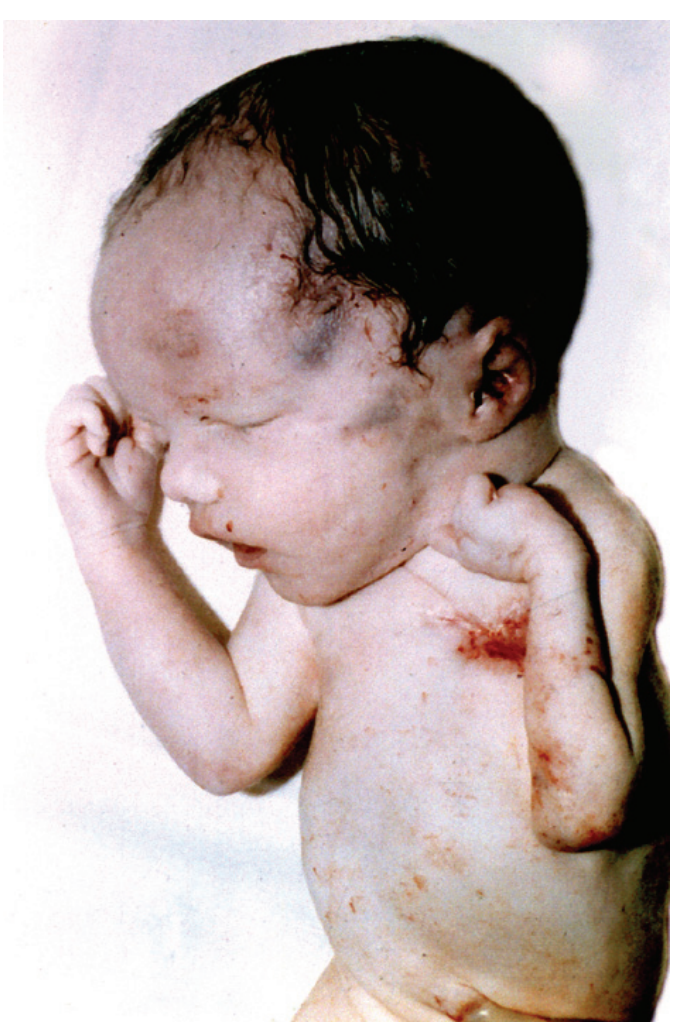

Figure 1. Female stillborn with cicatricial skin lesions involving the left side of chest, axilla, and shoulder as well as hypoplasia of the left upper limb after maternal varicella between the $13^{\text {th }}$ and $15^{\text {th }}$ gestational weeks.

intervillous thrombosis and chronic infarcts. VZV DNA could be detected by polymerase chain reaction (PCR) in the lungs, spleen, adrenal glands, bulbus oculi, and placenta. In addition, VZV DNA/antigens were localized in some organs by means of in situ hybridization/ monoclonal antibodies.

\subsection{Zoster During Pregnancy}

On the basis of current knowledge, zoster during preg- nancy is not associated with birth defects [15,23]. Although there are some reports of neonates with congenital malformations being born to mothers with history of zoster during early pregnancy, no case showed laboratory evidence of intrauterine infection with VZV. In addition, maternal zoster during the perinatal period does not cause problems for neonates [24] as they possess specific maternal IgG class antibodies and there is usually no longer viremic spread of VZV unless the woman is immunocompromised.

\section{VARICELLA-ZOSTER VIRUS INFECTIONS IN NEONATES}

\subsection{Neonatal Varicella}

During the perinatal period, maternal varicella can infect the infant by: 1) transplacental viremia, 2) ascending infection during birth, or 3) respiratory droplet/direct contact with infectious lesions after birth. Varicella of the neonate can be expected if a mother contracts chickenpox during the last 3 weeks of pregnancy. Chickenpox occurring in the first 12 days of life is described as intrauterine acquired neonatal varicella. Clinical observations suggest that the incubation period of intrauterine transmitted varicella from the beginning of maternal varicella rash to the onset of rash in the neonate is about 12 days, but it can be reduced to few days [4]. On the basis of these data, neonatal chickenpox occurring after the $12^{\text {th }}$ day of the neonatal period is most likely not transmitted by intrauterine infection, but it is acquired by postnatal VZV infection. Maternal chickenpox few days before or after delivery may cause life-threatening neonatal chickenpox. The disease was first recognized by Hubbard in 1878 [25]. To date, hundreds of cases have been reported [7].

The severity of intrauterine acquired neonatal chickenpox is closely related to the time of onset of maternal infection as transplacentally transmitted antibodies may reduce the severity of symptoms in the neonate. Fetuses 
exposed to VZV between 20 and 6 days before delivery may develop neonatal chickenpox however with nonfatal course. These neonates got maternal antibodies and have therefore a lower risk of complications. Generalized neonatal varicella associated with fatal course has to be expected if mothers develop varicella rash between 4-5 days before and 2 days after delivery [7] since these neonates did not acquire protecting maternal antibodies. Additionally, the cell-mediated immune response of the neonate is likely insufficient to retard the hematogeneous dissemination of VZV after transplacental spread [26]. Thus, a fatal outcome has been reported in nearly $20 \%$ of these cases (Table 3). Furthermore, there is a close relationship between the prognosis of intrauterine acquired neonatal varicella and the onset of disease in the neonate. A fatal outcome is more likely if the neonatal disease occurs between 5 and 10 days after delivery. To our knowledge, $23 \%$ of the neonates reported in the literature died from a disseminated and fulminant neonatal infection [7]. In comparison, neonatal varicella within the first 4 days after birth has usually been found to be mild (Table 3).

Case report [27]: Two days before delivery, the mother of a female neonate had chickenpox with characteristic skin rash. The girl was transferred from the nursery to the isolation ward and received $1.5 \mathrm{ml}$ varicellazoster immune globulin (VZIG) Zostergam ${ }^{\circledR}$. After one week, she was discharged home since she was healthy. On the tenth day, the girl was hospitalized again because of unclear skin lesions appearing on the face. One day later, she developed generalized varicella skin rash. The neonate died from respiratory distress on the $16^{\text {th }}$ day. Autopsy revealed typical varicella rash on the skin (Figure 2) and the mucous membrane of the mouth, confluent hemorrhagic-necrotizing pneumonia, necrotizing hepatitis as well as focal necroses of the intestinal mucous membranes, spleen, adrenal glands and brain. Virological investigations confirmed the diagnosis of varicella by detecting VZV DNA in liver tissue using PCR and in situ hybridization. By electron microscopy, intranuclear herpesvirus-like particles could be seen in specimens from skin lesions as well as in necrotic lesions of liver and lungs.

Postnatal VZV infections during the neonatal period have a low morbidity rate [28] as most neonates are protected by maternally derived antibodies. However, premature neonates younger than 28 weeks gestation must be considered to have an increased risk for severe varicella during the first 6 weeks after birth [29,30]. It has been suggested they have got no protecting maternal antibodies because of the reduced gestation period.

\subsection{Zoster in Neonates and Young Infants}

Nearly $20 \%$ of infants with intrauterine acquired VZV primary infection develop neonatal or infantile zoster, usually with uncomplicated course [18]. The disease is thought to represent reactivation of the virus after primary infection in uteri. The relatively short viral latency period may be explained by the immature cell-mediated immune response in young infants.

\section{LABORATORY DIAGNOSIS}

\subsection{Congenital Varicella Syndrome}

Most cases of CVS have been reported on the basis of the described main clinical symptoms without laboratory evidence of intrauterine infection. However, the causal relationship between maternal varicella infection and congenital abnormalities can be most convincingly verified by detection of viral DNA or viral antigens in the neonates [22]. Therefore, molecular biological methods should be regularly included in the diagnosis of CVS. In particular, cases presented with rare malformations or after sub-clinical maternal VZV infection need confirmation by virological methods, otherwise the causal relationship between maternal infection and congenital abnormalities remains doubtful [31]. Unlike in cases of intrauterine rubella or cytomegalovirus infection,

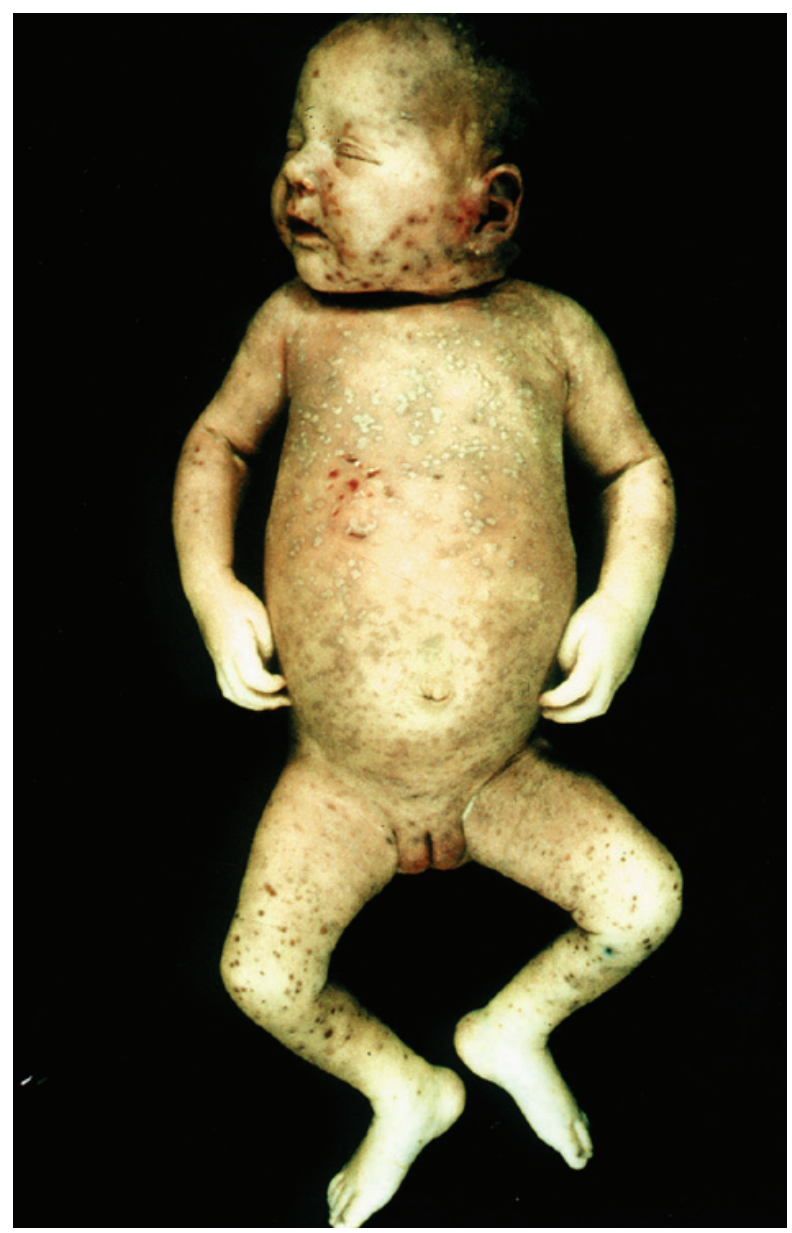

Figure 2. Female neonate with lethal neonatal varicella. 
Table 3. Prognosis of neonatal varicella without antiviral treatment in 136 term neonates cited in the literature.

\begin{tabular}{lcccc}
\hline Mother/Neonate & Total number & Day of onset of varicella & \multicolumn{2}{c}{ Number of cases of neonatal varicella } \\
Non-fatal & $57(100 \%)$ & 0 \\
Mother & 57 & $\geq 5$ days before delivery & $65(82 \%)$ & $14(18 \%)$ \\
& 79 & 4 days before to 2 days & $34(97 \%)$ & $1(3 \%)$ \\
Neonate* & 35 & after delivery & $36(77 \%)$ & $11(23 \%)$ \\
\hline
\end{tabular}

* Data of 54 neonates have not been described.

VZV has not been isolated in cell cultures from any neonate with CVS. Usually, the detection of virus-specific antibodies in neonates has been reported to confirm a suspected prenatal infection with VZV. Serologic diagnosis is mostly based on the persistence of VZV-specific IgG class antibodies beyond 7 months of life when maternal antibodies should normally have disappeared $[32,33]$. The presence of virus-specific IgM has only been described in about $25 \%$ of the cases with CVS [23]. The reason for that is primarily the low sensitivity of commercially distributed enzyme immuneo-assays, which are most frequently used to detect VZV-specific IgM. To establish a relationship between maternal VZV infection and congenital anomalies of neonates, the criteria listed in Table 4 should be used as guideline.

The differential diagnosis of CVS includes congenital infections caused by rubella virus, cytomegalovirus, herpes simplex virus (HSV), coxsackie virus or Toxoplasma gondii $[23,34,35]$ and the specific genetic disorder called MIDAS (Microphthalmus, Dermal Aplasia, Sclerokornea) syndrome [36], whose cardinal symptoms represent congenital skin defects in dermatomal distribution associated with microphthalmia.

\subsection{Neonatal Varicella and Varicella Pneumonia}

The diagnosis of neonatal varicella is usually based on the typical clinical picture. The characteristic point in

(1) Appearance of maternal varicella during pregnancy

(2) Neonate or fetus with

congenital skin lesions in dermatomal distribution and/or

neurological defects,

eye diseases,

limb hypoplasia

(3) Proof of intrauterine VZV infection by

detection of viral DNA using polymerase chain reaction and/or presence of specific IgM/persistence of IgG beyond 7 months of age, appearance of zoster during early infancy

time of infection and the maternal history of chickenpox during the last weeks of pregnancy have to be considered to diagnose the intrauterine acquired disease. Clinical findings have been usually confirmed by serological Table 4. Criteria used for diagnosis of congenital varicella syndrome.methods, but they are not useful for early diagnosis. For laboratory diagnosis of VZV infection, PCR technique should be used as method of choice. Suitable patient materials are skin swabs or biopsies, liquor specimens and tissue samples. HSV and enterovirus infections should be considered in differential diagnosis $[37,38]$. On suspicion of varicella pneumonia, a laboratory diagnosis is necessary for reason of differential diagnosis. As method of choice, the PCR should be used to detect viral DNA in broncho-alveolar lavage.

\section{MEASURES IN MATERNAL VARICELLA-ZOSTER VIRUS INFECTIONS}

\subsection{Preventive Measures}

An effective prophylaxis of chickenpox in pregnant women and neonates is only possible by active immunization of seronegative women before pregnancy. A live attenuated varicella vaccine has been shown to be safe and effective in preventing chickenpox in adults [39]. Varicella vaccine, as all live-attenuated vaccines, is contraindicated in pregnant women and pregnancy has to be avoided for at least 4 weeks following vaccination. The Pregnancy Registry managed by the Merck Research Laboratories (USA) in collaboration with the Centers for Disease Control and Prevention (USA), records women, who exposed to varicella vaccine during pregnancy or within 3 months before conception. Preliminary results showed no hints to any birth defects related to vaccine exposure [40,41]. In few cases, vaccines can develop breakthrough varicella that occurs 42 days after vaccination and represents wild virus infection [42]. Most diseases are very mild, the infectivity is relatively low and there is a low or no risk for complications [43]. Thus, the risk for CVS from breakthrough varicella can be regarded as considerably lower than that for CVS in unvaccinated women with varicella. However, prophylactic and therapeutic measures in women with breakthrough varicella should be considered as in unvaccinated women who develop varicella since data about the risk for CVS after breakthrough varicella are not available to date.

Non-immune pregnant women should be advised to avoid exposure to chickenpox and zoster. If pregnant 
women with a negative or indeterminate history of varicella have been exposed significantly to VZV by household contact, face-to-face contact for at least 5 minutes or indoors contact for more than 15 minutes, virus-specific IgG class antibodies should be measured immediately. If the woman is seronegative or there is an indeterminate or unknown status of immunity, she should be regarded as susceptible. Antibodies detected within 7-10 days of contact must have been acquired before exposure. For pregnant women, who were adequately vaccinated with 2 vaccine doses, routine serologic testing cannot be recommended since $99 \%$ of persons become seropositive after the second dose of varicella vaccination [44]. Furthermore, most currently used enzyme immunoassays are too insensitive to detect vaccine-induced VZV-specific IgG class antibodies [45] and sensitive procedures such as the fluorescent antibody to membrane antigen assay or tests for the determination of the cell-mediated immune response are too laborious and/or time consuming for daily routine. Recently, a new generation of VZV glycoprotein-based enzyme immunoassays has been shown to have higher sensitivity for the determination of VZV IgG [46].

In case of negative, indeterminate or unknown serologic status, the application of VZIG within $72(-96)$ hours has been recommended $[47,48]$ (Figure 3) intramuscularly at a concentration of $125 \mathrm{U} / 10 \mathrm{~kg}$ of body weight, up to a maximum of $625 \mathrm{U}$ [29] or $0.5 \mathrm{ml} / \mathrm{kg}$ of body weight [30]. A dosage of $1 \mathrm{ml} / \mathrm{kg}$ of body weight can be administered intravenously as alternative [30]. Even though the passive immunization does not prevent varicella, it may reduce most likely the risk of severe varicella as well as fetal infection. However, there is no evidence that this prevents fetal viremia or CVS. Thus, the primary reason for VZIG is to prevent severe maternal chickenpox and its complications, such as pneumonia. If there is a definitive past history of chickenpox, it is reasonable to assume that the woman is immune to varicella. Vaccinated pregnant women who were tested VZV IgG-negative should be managed as a seronegative pregnant woman without varicella vaccination. However, in most cases, seronegative vaccinees have most likely acquired VZV-specific cell-mediated immunity.

In the United States, VZV vaccine was licensed in 1995 and decreased the incidence of varicella by $85-90 \%$ in the decade following licensure as result of a vaccine coverage rate of about $80 \%$ [49]. Even though varicella incidence decreased most significantly in children aged 1-4 years, the incidence also declined nearly $75 \%$ among adults despite of low vaccination rates [50]. These data suggest that the universal childhood immunization, introduced also in Germany as the only country in Europe during 2004, has the potential to reduce the occurrence of varicella in pregnant women through herd immunity. However, recent publications demonstrate that varicella during pregnancy is still a problem in many countries which do not offer a routine universal childhood varicella immunization program $[51,52]$. In Italy, epidemiological data suggest that the risk of acquiring varicella during pregnancy is increasing [53]. Therefore, information programs are recommended to disseminate and to promote screenng and immunization against varicella in susceptible women of childbearing age [54].

\subsection{Diagnostic and Therapeutic Measures}

Mothers with varicella during the first or second trimester should be carefully monitored since intrauterine infection may lead to CVS. Fetal ultrasound and magnetic resonance imaging at 16 to 22 weeks gestational age or 5 weeks after infection can identify signs of CVS (Figure 3) [55,56]. Laboratory investigations for VZV DNA in placental villi, fetal blood or amniotic fluid and for VZV IgM in fetal blood are only indicated if suspicious fetal abnormalities can be detected [55]. However, several studies have shown that the presence of VZV DNA alone does not necessarily correlate with fetal disease [57]. Thus, the question of how severely the fetus is affected cannot be answered definitely. This and the low risk of CVS should be considered in counseling women with varicella in early pregnancy. Termination of pregnancy is only indicated if there are definitive signs of serious fetal abnormalities.

An antiviral treatment has immediately to be introduced at first signs of varicella pneumonia or other disseminated infections. As the only therapeutic agent, aciclovir is indicated in pregnant women. Aciclovir has to be administered orally at a dosage of $5 \times 800 \mathrm{mg}$ or intravenously at a concentration of $3 \times 10-15 \mathrm{mg} / \mathrm{kg}$ for 7-10 days. Zoster during pregnancy should only be treated with aciclovir in severe courses of the disease [58]. To date, there are no controlled studies concerning antiviral chemotherapy in preventing CVS [59].

\section{MEASURES IN NEONATAL VARICELLA-ZOSTER VIRUS INFECTIONS}

\subsection{Preventive Measures}

Mothers and neonates suffering from or being at risk of varicella have to be isolated on maternity wards. To reduce the mortality from neonatal chickenpox, the date of delivery may be postponed for several days to allow maternal antibodies to pass the placental barrier (Figure 3). However, there is only little experience with successful delay of labor when neonatal varicella must be expected $[60,61]$. The administration of aciclovir at a dosage of 5 x $800 \mathrm{mg}$ orally or 3 x $10-15 \mathrm{mg} / \mathrm{kg}$ intravenously for 7 days has been recommended for pregnant women within 24 hours of the varicella rash when the disease occurs within 4-5 days before delivery. VZIG is indicated for neonates whose mothers have signs and symptoms of varicella between 5 days before and 2 days after delivery 


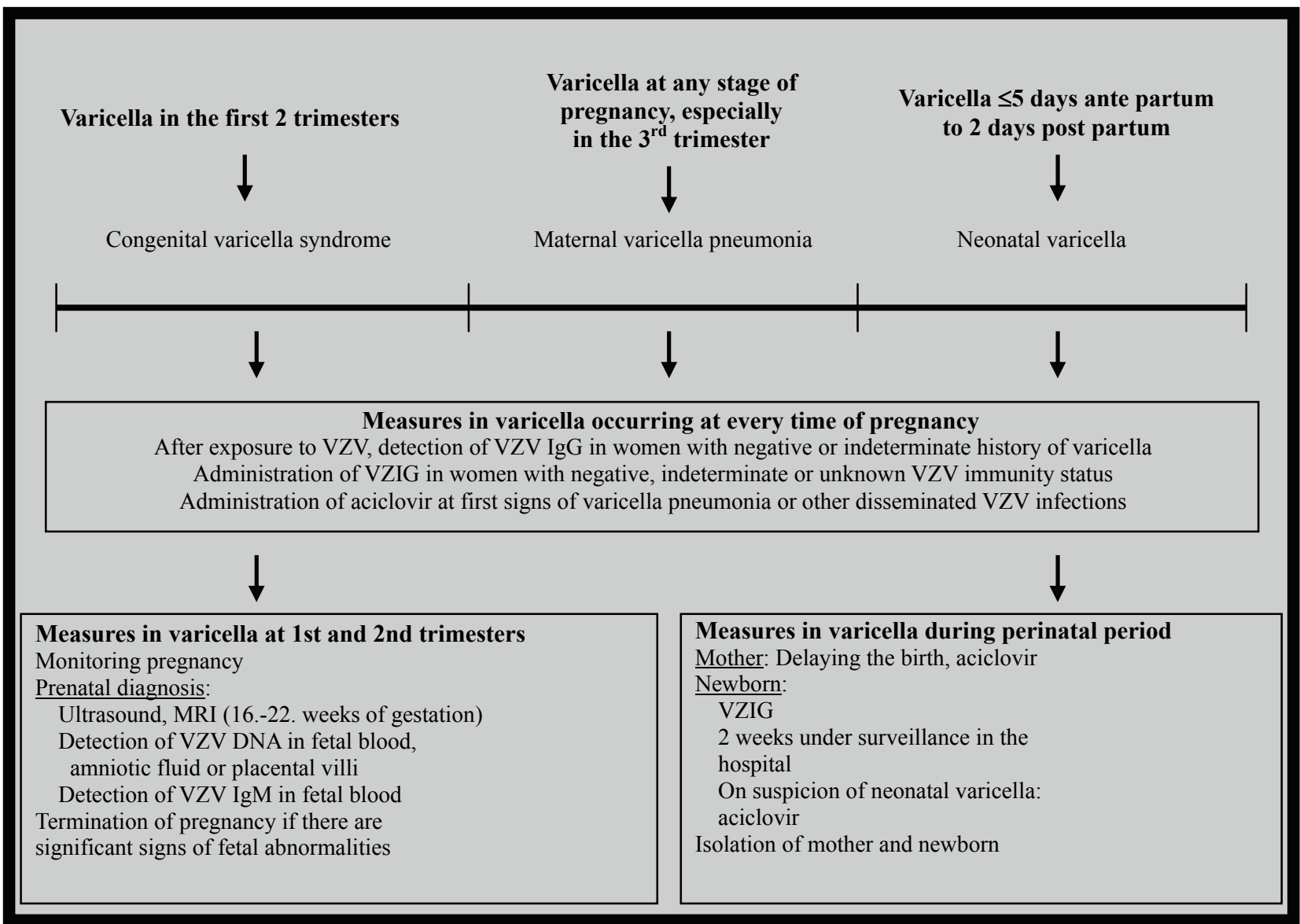

Figure 3. Measures in case of varicella during pregnancy depending on the point of time of infection; MRI: magnetic resonance imaging, VZIG: varicella-zoster immune globulin, VZV: varicella-zoster virus.

Table 5. Administration of varicella-zoster immune globulin (VZIG) and aciclovir in neonates to prevent neonatal varicella.

\begin{tabular}{|c|c|c|}
\hline \multicolumn{3}{|l|}{ VZIG after intrauterine exposure to VZV } \\
\hline $\begin{array}{l}\text { Neonates whose mothers develop varicella within } \\
5 \text { days before and } 2 \text { days after delivery }\end{array}$ & $\begin{array}{l}\text { Intravenously: } 1 \mathrm{ml} / \mathrm{kg} \text { [30] or intramus- } \\
\text { cularly: } 125 \mathrm{U} \text { [29] or } 0.5 \mathrm{mg} / \mathrm{kg} \text { [30] }\end{array}$ & $\begin{array}{l}\text { Immediately after birth or } \\
\text { onset of maternal rash }\end{array}$ \\
\hline \multicolumn{3}{|l|}{ VZIG after postnatal exposure } \\
\hline $\begin{array}{l}\text { Premature neonates with negative varicella his- } \\
\text { tory of the mother }\end{array}$ & $\begin{array}{l}\text { Intravenously: } 1 \mathrm{ml} / \mathrm{kg} \text { [30] or intramus- } \\
\text { cularly: } 125 \mathrm{U} \text { [29] or } 0.5 \mathrm{mg} / \mathrm{kg} \text { [30] }\end{array}$ & $\begin{array}{l}\text { Within } 96 \text { hours after expo- } \\
\text { sure }\end{array}$ \\
\hline $\begin{array}{l}\text { Premature neonates }<28 \text { weeks gestation or } \\
<1,000 \mathrm{~g} \text { birth weight independent of maternal } \\
\text { varicella history }\end{array}$ & $\begin{array}{l}\text { Intravenously: } 1 \mathrm{ml} / \mathrm{kg} \text { [30] or intramus- } \\
\text { cularly: } 125 \mathrm{U} \text { [29] or } 0.5 \mathrm{mg} / \mathrm{kg} \text { [30] }\end{array}$ & $\begin{array}{l}\text { Within } 96 \text { hours after expo- } \\
\text { sure }\end{array}$ \\
\hline \multicolumn{3}{|l|}{ Antiviral treatment of neonatal varicella } \\
\hline Suspected neonatal varicella & $\begin{array}{lllll}\begin{array}{l}\text { Aciclovir intravenously: } \\
\mathrm{mg} / \mathrm{kg}\end{array} & \mathrm{x} & 10-15 \\
\end{array}$ & Length of therapy: 5-7 days \\
\hline
\end{tabular}

(Table 5). Passive immunization is probably not necessary for neonates whose mothers have sings of varicella $>5$ days before or $>2$ days after delivery $[14,62]$ because those neonates are not at risk of severe neonatal varicella. Hospitalized premature neonates, younger than 28 weeks gestation, who are exposed to $\mathrm{VZV}$, have to receive
VZIG, regardless of the maternal history of chickenpox as these neonates may not have acquired maternal antibodies (Table 5) [29]. Following treatment, these neonates should be under surveillance in the hospital for 2 weeks, i.e. to the end of incubation period $[14,30]$. When a neonate who has received VZIG is discharged home, it 
should be made clear to the parents that prompt hospital review should be undertaken if the neonate becomes unwell or develops rash. It has been generally accepted that passive immunization of the neonate can modify the clinical course of neonatal varicella but it does not prevent the disease and, although decreased, the risk of death is not completely eliminated $[63,64]$.

\subsection{Therapeutic Measures}

An antiviral treatment of neonates with CVS has only been described in few cases [65-67]. Clinical observations suggest that aciclovir therapy may be helpful especially to stop the progression of eye diseases or to prevent neurological diseases after VZV reactivations. Suspected cases of neonatal chickenpox should be treated promptly with aciclovir (Figure 3, Table 5). Prophylactic intravenous administration of aciclovir can prevent neonatal varicella or can reduce the severity of the disease markedly [68]. Well-controlled studies on the use of aciclovir in neonates have not been reported to date [59].

\section{REFERENCES}

[1] Wutzler, P., Färber, I., Wagenpfeil, S., Bisanz, H., and Tischer, A. (2001) Seroprevalence of varicella-zoster virus in the German population. Vaccine, 20, 121-124.

[2] Sever, J. and White, L.R. (1968) Intrauterine viral infections. Annual Review of Medicine, 19, 471-486.

[3] Stagno, S. and Whitley, R.J. (1985) Herpesvirus infections of pregnancy (Part II): Herpes simplex virus and varicella-zoster virus infections. New England Journal of Medicine, 313, 1327-1330.

[4] Enders, G. and Miller, E. (2000) Varicella and herpes zoster in pregnancy and the newborn. In Arvin, A.M., Gershon, A.A. (eds.), Varicella-Zoster Virus, Virology and Clinical Management, University Press, Cambridge, 317-347.

[5] Robert Koch-Institut (2003) Zur Seroprävalenz gegen Varicella-Zoster-Virus und zur Verlässlichkeit anamnestischer Angaben. Epidemiologisches Bulletin, 43, 347.

[6] Smego, R.A. Jr. and Asperille, M.O. (1991) Use of acyclovir for varicella pneumonia during pregnancy. Obstetrics \& Gynecology, 78, 1112-1116.

[7] Sauerbrei, A. and Wutzler, P. (2001) Neonatal varicella. Journal of Perinatology, 21, 545-549.

[8] Baren, J.M., Nenneman, P.L., and Lewis, R.J. (1996) Primary varicella in adults: pneumonia, pregnancy, and hospital admission. Annals of Emergency Medicine, 28, 165-169.

[9] Harris, R.E. and Rhoades, E.R. (1965) Varicella pneumonia complicating pregnancy: Report of a case and review of literature. Obstetrics \& Gynecology, 25, 734-740.

[10] Harger, J.H., Ernest, J.M., Thurnau, G.R., Moawad, A., Thom, E., Landon, M.B., Paul, R., Miodovnik, M., Dombrowski, M., Sibai, B., Van Dorsten, P., McNellis, D., and National Institute of Child Health and Human Development Network of Maternal-Fetal Medicine Units (2002) Frequency of congenital varicella syndrome in a prospective cohort of 347 pregnant women. Obstetrics \& Gynecology, 100, 260-265.

[11] Haake, D.A., Zakowski, P.C., Haake, D.L., and Bryson, X.J. (1990) Early treatment with acyclovir for varicella pneumonia in otherwise healthy adults: Retrospective controlled study and review. Reviews of Infectious Diseases, 12, 788-798.

[12] Chandra, P.C., Patel, H., Schiavello, H.J., and Briggs, S.L. (1998) Successful pregnancy outcome after complicated varicella pneumonia. Obstetrics \& Gynecology, 92, 680-682.

[13] Sauerbrei, A. and Wutzler, P. (2005) Varicella-zoster virus infections during pregnancy: Epidemiology, clinical symptoms, diagnosis, prevention and therapy. Current Pediatric Reviews, 1, 205-216.

[14] Prober, C.G., Gershon, A.A., Grose, C., McCracken, G.H., and Nelson, J.D. (1990) Consensus: Varicella-zoster infections in pregnancy and the perinatal period. Pediatric Infectious Disease Journal, 9, 865-869.

[15] Enders, G., Miller, E., Cradock-Watson, J., Bolley, I., and Ridehalgh, M. (1994) Consequences of varicella and herpes zoster in pregnancy: Prospective study of 1739 cases. Lancet, 343, 1548-1551.

[16] Pastuszak, A.L., Levy, M., Schick, B., Zuber, C., Feldkamp, M., Gladstone, J., Bar-Levy, F., Jackson, E., Donnenfeld, A., Meschino, W., and Koren, G. (1994) Outcome after maternal varicella infection in the first 20 weeks of pregnancy. New England Journal of Medicine, 330, 901-905.

[17] Laforet, E.G. and Lynch, C.J. Jr. (1947) Multiple congenital defects following maternal varicella. New England Journal of Medicine, 236, 534-537.

[18] Sauerbrei, A. and Wutzler, P. (2003) Das fetale Varizellensyndrom. Monatsschrift Kinderheilkunde, 151, 209-213.

[19] Schulze, A. and Dietzsch, H.J. (2000) The natural history of varicella embryopathy: A 25-year follow-up. Journal of Pediatrics, 137, 871-874.

[20] Higa, K., Dan, K., and Manabe, H. (1987) Varicellazoster virus infections during pregnancy: Hypothesis concerning the mechanisms of congenital malformation. Obstetrics \& Gynecology, 69, 214-221.

[21] Grose, C. (1989) Congenital varicella-zoster virus infection and the failure to establish virus-specific cell-mediated immunity. Molecular Biology and Medicine, 6, 453-462.

[22] Sauerbrei, A., Müller, D., Eichhorn, U., and Wutzler, P. (1996) Detection of varicella-zoster virus in congenital varicella syndrome: A case report. Obstetrics \& Gynecology, 88, 687-689.

[23] Sauerbrei, A. and Wutzler, P. (2000) The congenital varicella syndrome. Journal of Perinatology, 20, 548-554.

[24] Miller, E., Cradock-Watson, J.E., and Ridehalgh, M.K. (1989) Outcome in newborn babies given anti-varicellazoster immunoglobulin after perinatal maternal infection with varicella-zoster virus. Lancet, 2, 371-373.

[25] Hubbard, T.W. (1878) Varicella occurring in an infant twenty four hours after birth. British Medical Journal, 1,822 .

[26] Baba, K., Yabuuchi, H., Takahashi, M., and Ogra, P.L. (1982) Immunologic and epidemiologic aspects of varicella infection acquired during infancy and early childhood. Journal of Pediatrics, 100, 881-885.

[27] Nikorowitsch, R., Wiedersberg, H., Ruikold, E., Zwahr, 
C., Althen, B., Holzhausen, H.J., and Sauerbrei, A. (1989) Tödlicher Verlauf einer konnatalen Varizelleninfektion. Zeitschrift für Klinische Medizin, 44, 1961-1963.

[28] Heidl, M. (1985) Varicella-Zoster-Virus-Infektion in der Schwangerschaft, beim Neugeborenen und jungen Säugling. Zeitschrift für Klinische Medizin, 40, 245-250.

[29] Advisory Committee on Immunization Practices (ACIP) (1996) Prevention of varicella. Morbidity and Mortality Weekly Report, 45, 1-36.

[30] Deutsche Gesellschaft für Pädiatrische Infektiologie (2003) Handbuch 2003: Infektionen im Kindesalter, Futuramed, München, pp. 732-739.

[31] Al-Katawee, Y.A., Al-Hassoun, Y.A., Taha, M.N., and Al-Moslem, K. (2005) Congenital varicella-zoster virus infection: A rare case of severe brain and ocular malformations without limb or cutaneous involvement in a newborn after maternal subclinical infection. Saudi Medical Journal, 26, 869-871.

[32] Akisu, M., Yalaz, M., Aksu, G., Arslanoglu, S., Genel, F., Kutukculer, N., and Kultursay, N. (2003) Maternally acquired varicella-zoster virus antibodies disappear at 6 months of age in prematurely born children. Panminerva Medicine, 45, 155-156.

[33] Gershon, A.A., Raker, R., Steinberg, S., Topf-Olstein, B., and Drusin, L.M. (1976) Antibody to varicella-zoster virus in parturient women and their offspring during the first year of life. Pediatrics, 58, 692-696.

[34] Koskimies, O., Lapinleimu, K., and Saxén, L. (1978) Infections and other maternal factors as risk indicators for congenital malformations: A case-control study with paired serum samples. Pediatrics, 61, 832-837.

[35] Johansson, A.B., Rassart, A., Blum, D., Van Beers, D., and Liesnard, C. (2004) Lower-limb hypoplasia due to intrauterine infection with herpes simplex virus type 2: Possible confusion with intrauterine varicella-zoster syndrome. Clinical Infectious Diseases, 38, e57-62.

[36] Spranger, S., Stute, H., Blankenagel, A., Jauch, A., Hager, D., and Tariverdian, G. (1998) MIDAS-syndrom: Eine X-chromosomale Erkrankung: Differenzialdiagnose zum kongenitalen Varizellensyndrom. Monatsschrift Kinderheilkunde, 146, 761-765.

[37] Gershon, A.A. (1998) Varicella-zoster virus. In Feigin, R.D. and Cherry, J.D. (eds.), Textbook of Pediatric Infectious Diseases (4th Edition), W. B. Saunders Company, Philadelphia, 1769-1777.

[38] Sauerbrei, A., Glück, B., Jung, K., Bittrich, H., and Wutzler, P. (2000) Congenital skin lesions caused by intrauterine coxsackievirus B3 infection: A case report. Infection, 28, 326-328.

[39] Gershon, A.A., Steinberg, S.P., and The National Institute of Allergy and Infectious Disease Varicella Vaccine Collaborative Study Group (1990) Live attenuated varicella vaccine: Protection in healthy adults compared with leukemic children. Journal of Infectious Diseases, 158, 661-666.

[40] Shields, K.E., Galil, K., Seward, J., Sharrar, R.G., Cordero, J.F., and Slater, E. (2001) Varicella vaccine exposure during pregnancy: Data from the first 5 years of the pregnancy registry. Obstetrics \& Gynecology, 98, 14-19.

[41] Wilson, E., Goss, M.A., Marin, M., Shields, K.E., Seward, J.F., Rasmussen, S.A., and Sharrar, R.G. (2008) Varicella vaccine exposure during pregnancy: Data from 10 years of pregnancy registry. Journal of Infectious
Diseases, 197 (2), S178-S184.

[42] Watson, B. (2002) Varicella: A vaccine preventable disease? Journal of Infection, 44, 220-225.

[43] Vázquez, M. and Shapiro, E.D. (2005) Varicella vaccine and infection with varicella-zoster virus. New England Journal of Medicine, 352, 439-440.

[44] Kuter, B.J., Ngai, A., Patterson, C.M., Staehle, B.O., Cho, I., Matthews, H., Provost, P.J., and White, C.J. (1995) Safety, tolerability, and immunogenicity of two regimens of Oka/Merck varicella vaccine $\left(\right.$ Varivax $^{\circledR}$ ) in healthy adolescents and adults. Vaccine, 13, 967-972.

[45] Sauerbrei, A. and Wutzler, P. (2004) Labordiagnostik der Varizellen. Kinderärztliche Praxis, Sonderheft Impfen, 18-21.

[46] Sauerbrei, A. and Wutzler, P. (2006) Serological detection of varicella-zoster virus-specific immunoglobulin $G$ by an enzyme-linked immunosorbent assay using glycoprotein antigen. Journal of Clinical Microbiology, 44, 3094-3097.

[47] Robert Koch-Institut (2004) Empfehlungen der Ständigen Impfkommission (STIKO) am Robert Koch Institut/Stand: Juli 2004. Epidemiologisches Bulletin, 30, 235-250.

[48] Royal College of Obstetricians and Gynecologists (2001) Chickenpox in pregnancy, Guideline No. 13.

[49] Guris, D., Jumaan, A.O., Mascola, L., Watson, B.M., Zhang, J.X., Chaves, S.S., Gargiullo, P., Perella, D., Civen, R., and Seward, J.F. (2008) Chancing varicella epidemiology in active surveillance sites: United States 1995-2005. Journal of Infectious Diseases, 197(2), S71-S75.

[50] Marin, M., Watson, T.L., Chaves, S.S., Civen, R., Watson, B.M., Zhang, J.X., Perella, D., Mascola, L., and Seward, J.F. (2008) Varicella among adults: Data from active surveillance project, 1995-2005. Journal of Infectious Diseases, 197(2), S94-S100.

[51] Harish, R., Jamwal, A., and Dang, K. (2009) Congenital varicella syndrome/VZV fetopathy. Indian Journal of Pediatrics, DOI 10.1007/s12098-009-0259y, in press.

[52] Auriti, C., Piersigilli, F., De Gasperis, M.R., and Seganti, G. (2009) Congenital varicella syndrome: Still a problem? Fetal Diagnosis and Therapy, 25, 224-229.

[53] Gabutti, G., Penna, C., Rossi, M., Salmaso, S., Rota, M.C., Bella, A., Crovari, P., and Serological Study Group (2001) The seroepidemiology of varicella in Italy. Epidemiology and Infection, 126, 433-440.

[54] Pandolfi, E., Chiaradia, G., Moncada, M., Rava, L., and Tozzi, A.E. (2009) Prevention of congenital rubella and congenital varicella in Europe. Eurosurveillance, 14, 1-5.

[55] Pretorius, D.H., Hayward, I., Jones, K.L., and Stamm, E. (1992) Sonographic evaluation of pregnancies with maternal varicella infection. Journal of Ultrasound in Medicine, 11, 459-463.

[56] Verstraelen, H., Vanzieleghem, B., Deroort, P., Vanhaesebrouck, P., and Temmerman, M. (2003) Prenatal ultrasound and magnetic resonance imaging in fetal varicella syndrome: Correlation with pathology findings. Prenatal Diagnosis, 23, 705-709.

[57] Mouly, F., Mirlesse, V., Meritet, J.F., Rozenberg, F., Poissonier, M.H., Lebon, P., and Daffos, F. (1997) Prenatal diagnosis of fetal varicella-zoster virus infection with polymerase chain reaction of amniotic fluid in 107 cases. American Journal of Obstetrics \& Gynecology, 177, 894-898. 
[58] Gross, G., Schofer, H., Wassilev, S., Friese, K., Timm, A., Guthoff, R., Pau, H.W., Malin, J.P., Wutzler, P., and Doerr, H.W. (2003) Herpes zoster guideline of the German Dermatology Society (DDG). Journal of Clinical Virology, 26, 277-289.

[59] Tan, M.P. and Koren, G. (2006) Chickenpox in pregnancy: Revisited. Reproductive Toxicology, 21, 410-420.

[60] Paulman, P.M. and McLellan, R. (1990) Varicella during pregnancy: The timing of effective treatment. Journal of the American Board of Family Practice, 3, 121-123.

[61] Zieger, W., Friese, K., Weigel, M., Becker, K.P., and Melchert, F. (1994) Varizellen-Infektion am Geburtstermin. Zeitschrift für Geburtshilfe und Perinatologie, 198, 134-137.

[62] Miller, E. (1994) Varicella-zoster virus infection in pregnancy. Archives of Disease in Childhood, 70, F157-158.

[63] Holland, P., Isaacs, D., and Moxon, E.R. (1986) Fatal neonatal varicella infection. Lancet, 2, 1156.
[64] King, S.M., Gorensek, M., Ford-Jones, E.L., and Read, S.E. (1986) Fatal varicella-zoster infection in a newborn treated with varicella-zoster immunoglobulin. Pediatric Infectious Diseases, 5, 588-589.

[65] Wutzler, P., Sauerbrei, A., Scholz, H., Müller, D., und Wiedersberg, H. (1990-1991) Varicella-Zoster-Virusinfektionen in der Schwangerschaft. Pädiatrische Praxis, 41, 213-224.

[66] Sauerbrei, A., Pawlak, J., Luger, C., and Wutzler, P. (2003) Intracerebral VZV reactivation in congenital varicella syndrome? A case report. Developmental Medicine \& Child Neurology, 45, 837-840.

[67] Schulze-Oechtering, F., Roth, B., Enders, G., and Grosser, R. (2004) Kongenitales Varizellensyndrom: Besteht eine Infektionsgefahr für die Umgebung? Deutsche Medizinische Wochenschrift, 208, 25-28.

[68] Carter, P.E., Duffty, P., and Lloyd, D.J. (1986) Neonatal varicella infection. Lancet, 2, 1459-1460. 